\title{
Contracting as Part of New Public Management: Focus on Services Provided for Patients with Alzheimer's Disease in the Czech Republic
}

\author{
Daniela KANDILAKI, Kristina RANDLOVÁ and Peter PAŽITNÝ* \\ Prague University of Economics and Business, Prague, Czech Republic; daniela.kandilaki@vse.cz; \\ rank01@vse.cz; peter.pazitny@vse.cz \\ * Corresponding author: peter.pazitny@vse.cz
}

\begin{abstract}
In this article we focus on contracting as a tool of modern public administration and we aim to underline, that contracting is widely used for securing social and healthcare services for patients with Alzheimer's disease. In this context, we also see contracting as useful tool for assessing the costs of these services, since the "price" of the contract can be seen as its costs from the perspective of the customer, which is in this case the public system (regions), the health insurance funds and the families and patients themselves. Also, it is important to highlight, that the "price" of the contract between the public sector and the providers does not at all correspond to real costs that occur to providers of social care, so these providers can many times be underfinanced and seek financial resources also from other sources.
\end{abstract}

Keywords: new public management; contracting; social services; healthcare services; Czech Republic

JEL Classification: H75; J14; J24

\section{Introduction}

New public management (NPM) is a concept that applies management techniques from the private to the public sector. This innovation applies tools to the public system with an aim to improve its efficiency, effectiveness and financial stability, taking into account the specificities of public services. The NPM is a deliberately adopted measure aimed at promoting responsible and better service delivery, reducing inefficiencies in public administration and preventing misuse of resources. In this sense, the citizen is perceived as a customer who receives public sector services.

NPM reforms often require political leadership, institutional reform, and a shift in organizational culture. For effective implementation, it is necessary to move from hierarchical management and control to more market relationships. Such a transformation in organizational culture cannot be achieved quickly, it is a long-lasting process. During the implementation of the elements of the NPM, the actors must, among other things, deal with the reluctance of those who were satisfied with the previous system and are not willing to give up their influence.

This article aims to: (1) define contracting as part of NPM, (2) introduce contracting as a vital part of providing social services in Czech Republic and (3) discuss, that contracting can 
be a baseline approach for providing care for patients with Alzheimer's Disease and can be a good benchmark for assessing cost related to this disease without knowing the real costs of providers.

\section{Methodology}

In this article, a qualitative analysis of data and related documents was applied. The work draws on publications that deal with the issue of modern trends in corporate administration, specifically New public management. From the tools of New public management, contracting of social services in the Czech environment is selected and analyzed in more detail. Important part of the information sources were documents describing the functioning and financing of social services in the Czech Republic. The information gathered from various sources (mainly the 14 regions) is grouped and viewed as a whole, which discovers interesting causality and interconnection of individual facts.

From methodological point of view, we are also focusing on contracting as baseline factor for securing social and healthcare services for patients with Alzheimer's Disease (AD). This methodology for expenditure monitoring built in this way has a key advantage. It is consistent across all three sectors and it shares the view of the contracting entity. In the health care system, it is the health insurance company, in the social system it is the region, and, in the family, it is the caring family itself. The common denominator is therefore the willingness to contract and the willingness to pay for the service. Thus, this contracting methodology can in no way calculate the real costs of individual providers, but that is not its purpose either.

\section{Results}

\subsection{New Public Management}

The NPM was one of the main approaches to public sector reform adopted by many Western nations between the early 1980s and the mid-1990s (Gruening, 2001). The United Kingdom is considered to be the place of origin and the starting point for subsequent development around the world. In adopting the NPM as a new direction, there are differences in the implementation of managerial change not only between countries, but also between different sectors. Differences in the implementation of managerial changes affect different priorities and different goals. The instruments of the NPM vary from country to country, but the core of the instruments and the main idea remain the same. The NPM core includes the following items:

- Separate performance from policies

- More autonomy for line managers in operational management, both in policy development and implementation

- Management and control based on measured results

- Public institutions must formulate their goals in terms of results and outputs

- Production must be subject to a constant comparison of quality and prices.

From an implementation perspective, we observe two categories of NPM (Pollitt et al., 2007). The first category consists of countries that have decided since 1980 to follow the path 
of intensive implementation of the NPM (Great Britain, New Zealand). The second category includes countries that have implemented only some parts of the NPM (e.g., the Nordic countries of Europe, part of France and Italy, Spain). A separate chapter are the countries of Eastern and Central Europe implementing the NPM, mainly due to the urging of the European Union and the IMF. Among the tools of New public management used in the Czech Republic, we can include budgeting, controlling, delegation, motivation, communication, elements of competition, user payments, benchmarking, privatization, contracting, decentralization and change of legal form.

The impact of NPM reforms is diverse and it would be a mistake to assume that the implementation of the NPM and its individual instruments brings only positives. Hood and Dixon (2015), discussing the theoretical principles of the NPM and their implementation, point out that the NPM did not produce a public administration that would cost less resources and work better, rather the opposite is true. Dan et al. (2015), created reviews and evaluations of 32 empirical articles related to the application of NPM, from which resulted a classification of 7 possible impacts of the implementation of NPM systems (Table 1). According to Dan, it can be stated that none of the analyzed articles evaluated the reforms based on the elements of the NPM as reforms completely unsuccessful, but also as completely successful. Most of the studies analyzed (18) can be classified as type V. "NPM reforms can have significant positive effects but can be hampered by insufficient administrative capacity or an unsatisfactory context". The idea underlying this category is that there is some evidence of positive impacts, but the evidence is less convincing due to barriers like lack of capacity or contextual factors hampering reform. Last, but not least, the concept of NPM has also radically increased institutional and political complexity.

Table 1. Impacts of the implementation of New public management. (Dan et al., 2015)

\begin{tabular}{|c|l|}
\hline I. & NPM reforms do not work regardless of administrative capacity and type of context \\
\hline II. & NPM reforms do not work mainly due to insufficient administrative capacity \\
\hline III. & NPM reforms do not work mainly due to an inappropriate context \\
\hline IV. & NPM reforms work, although they may lead to some unintended consequences and trade-offs \\
\hline V. & $\begin{array}{l}\text { NPM reforms can have significant positive effects, but are limited by administrative capacity or an } \\
\text { unsatisfactory context may be limited }\end{array}$ \\
\hline VI. & NPM reforms work, although they may lead to some unintended consequences and trade-offs \\
\hline VII. & NPM reforms usually always work \\
\hline
\end{tabular}

The company's setting and a certain skepticism about the elements of the NPM gave way over time to the development of the concept of Post-New public management. Authors Dreschler and Randmaliiv (2015) present the development of NPM to Post-NPM in several ways. One of them is the model of the Neo-Weber state, which takes over the positive elements of the NPM. Other directions of development include, in particular, the New Public Administration or coordination emphasizing Joint-Up Governance and Whole-ofGovernance. These directions gradually led to the Post-NPM, which characterizes public administration today (Kandilaki, 2019). 


\subsection{Contracting}

Contracting is one of the NPM tools. The basis of this instrument are contractual agreements between a public body and a usually private (in some cases public) provider. When using this principle, the "costs" for service delivery are viewed as expenditures from the perspective of the customer, which in this case is the public sector. Thus, the contracting approach does not take into account the real costs of the provider, but the "costs" are determined by the payment, subsidy or the price of the contract.

In Czech Republic, contracting is widely used in the field of social services, which includes a wide range of actors and multiple sources of funding. The mechanism for financing social services is shown in Figure 1. Due to large number of stakeholders, it is necessary to contract all individual relationships, both in terms of control over the whole process and financial transparency.

Social services are paid from (1) state budget, (2) regional budgets, (3) municipalities, (4) grants, (5) public health insurance, as well as (6) direct payments from service users. Users of social services can be allocated a financial allowance for care for the necessary services, which is paid to them by the state from the public budget every month. A small percentage of income is also made up of founders' contributions and donations. The majority of financial resources comes from contracts with regional authorities, which publish their contracting strategies and policies regularly, which increase transparency of procedures and controls. Contracting can then be an effective tool of management, benchmarking and control (Pažitný \& Kandilaki, 2020).

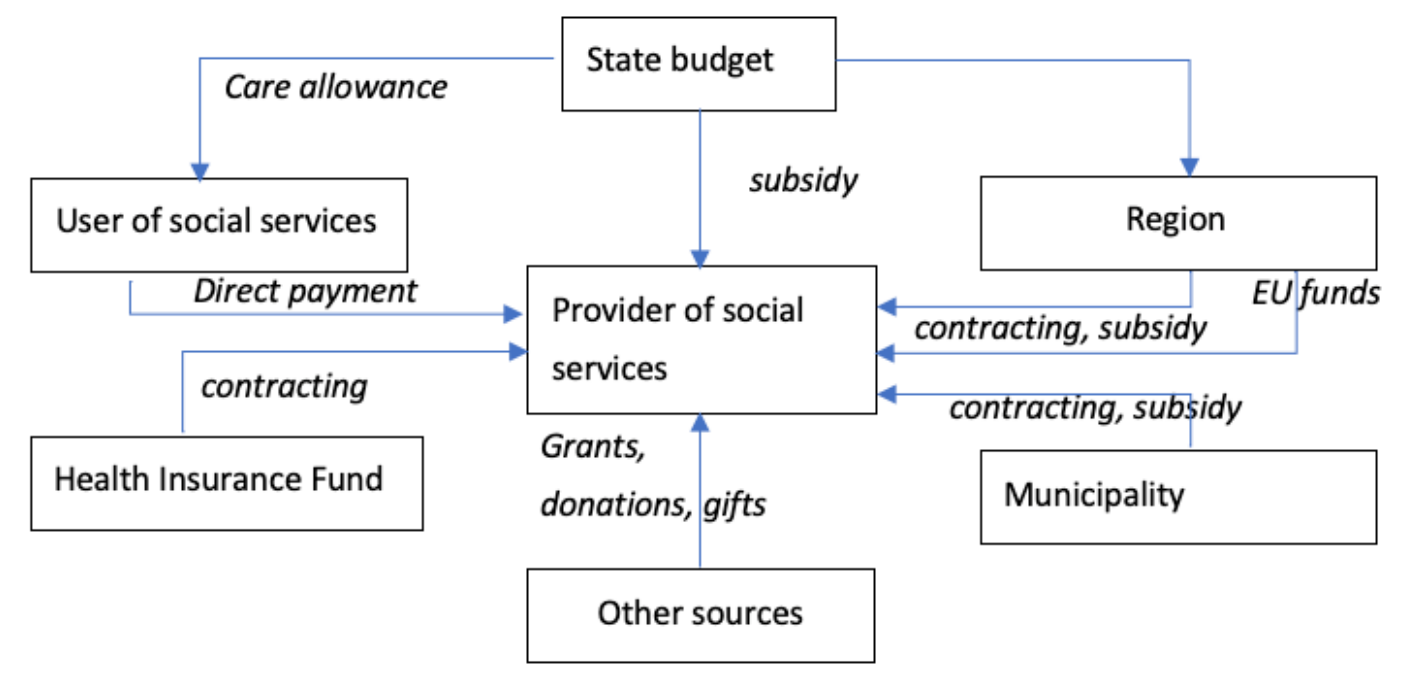

Figure 1. Mechanism of financing social and health services. (Kučerová, 2014)

\subsection{Contracting Services for Patients with Alzheimers Disease (AD)}

According to this principle of contracting, there are three main systems in which services for patients with $\mathrm{AD}$ are contracted. Health system, social system and family. In the health care system, the health insurance company contracts and the patient uses the healthcare services. In the social system of the service, the region contracts and the service are used by the patient. In family care, the service is contracted directly by the patient or family. 
Contracting in the healthcare system. Health services provided to patients with AD are defined by a contract between the health insurance company and the providers. Resources for reimbursement are from the health fund of health insurance companies. Patient participation is very limited in this case. Contracts with health insurance fund cover mainly the provision of outpatient services, inpatient services and medicines. The main source of income from public health insurance is compulsory wage deductions. The scope of paid services and the conditions for their payment are regulated by Act No. 48/1997 Coll.

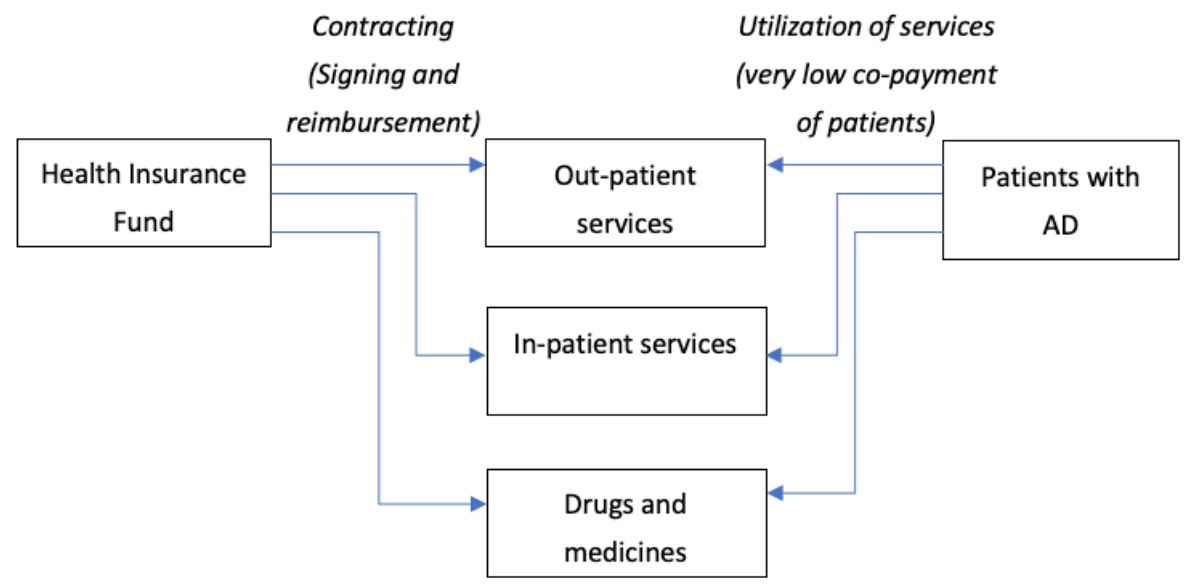

Figure 2. Mechanism of contracting healthcare services for patients with AD

Contracting in the social system works differently in each region, but in all regions, we can recognize common features. The regional network of services represents a network of social services, which are included in the contracting base of the region. Each region has its own strategy for including social services in the network. Social services can be divided into inpatient, outpatient and field care. Field and outpatient services are most often contracted in the form of fulltime equivalents (FTE) or hours. For inpatient services, contracting per bed is used. The amount of the subsidy per full-time equivalent / bed consists of several sources (subsidies from the ministry, regions, participation of the municipality), while almost every service requires a financial participation of the client. The amount of participation is defined by the rules of the region. The health insurance company can also pay extra for individual types of services.

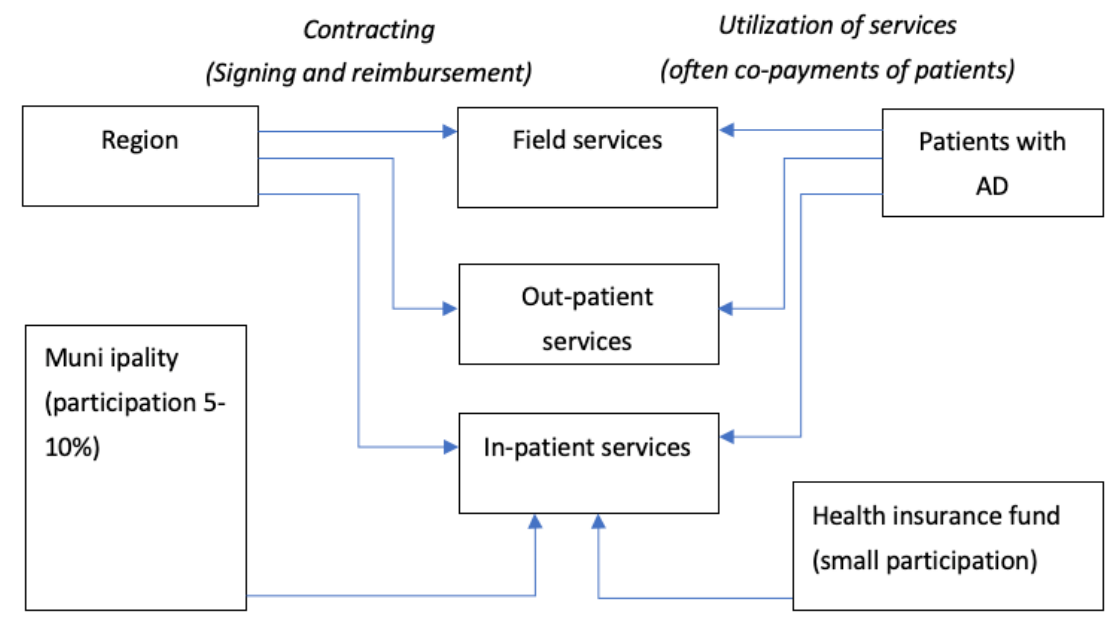

Figure 3. Mechanism of contracting social services for patients with AD 
Contracting by the family. A large number of patients do not receive any medical or social services (or use them to a minimal extent) and are cared for by their loved ones, spouse, partner, family, or friends. These patients are mostly at home. Unofficial careers, homes (gray zone), are also often sought after. A typical example of the gray zone is alcoholics, because in the official social system, alcoholism is a contradiction to the provision of a service. Many patients who are at home may have the first stages of the disease, or they may be patients with a higher degree who are not hospitalized for various reasons. This is due to waiting times or because the family takes care of the patient itself. Their costs can be divided into 3 parts: (1) Direct health and social expenditure, (2) Indirect medical expenses and (3) Indirect costs.

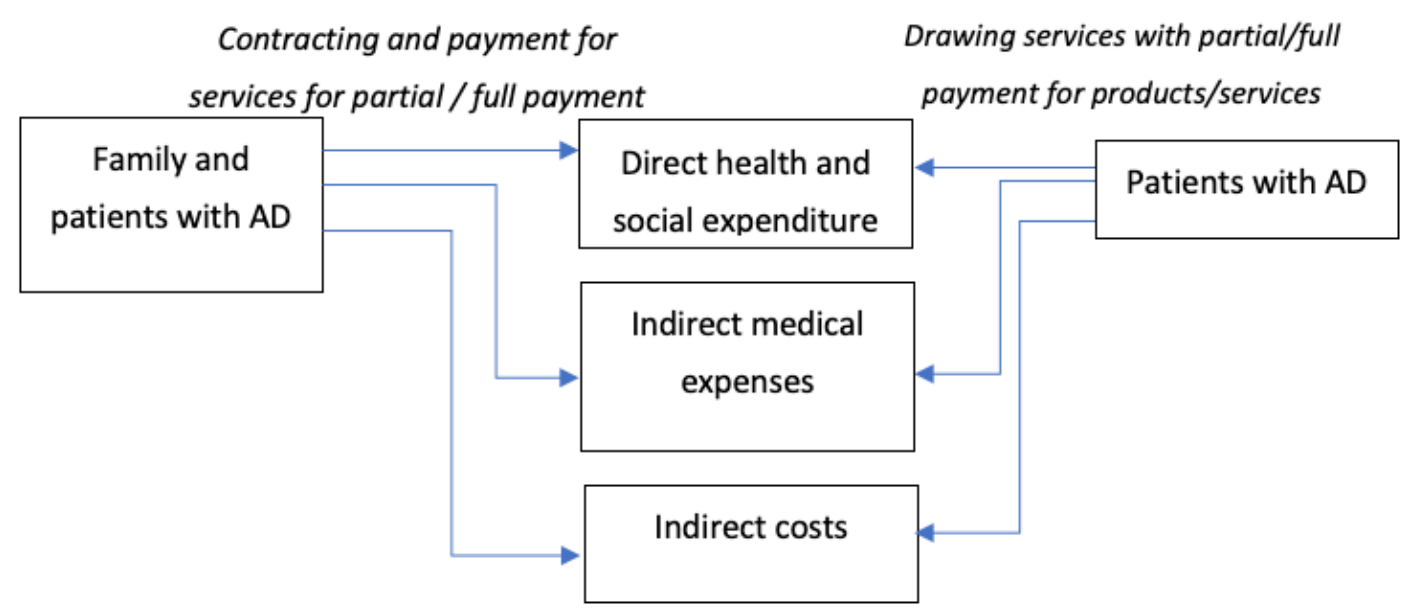

Figure 4. Mechanism of contracting health and social services for patients with AD

In the case of contracting by the client (its family), the set prices in the social services are mainly covered by the region, the healthcare services have the client's financial participation as a rule. An indispensable part of contracting are agreements on cooperation in the provision of social and health services. These are contracts between providers at the same or similar level of the hierarchy in case one provider is not able to cover all services provided to users. Cooperation agreements usually have a price for services also fixed using a contracting approach. (MLSA, 2019; Pažitný \& Kandilaki, 2020).

\section{Discussion}

Regarding the technical requirements, the concluded contracts must contain all the usual prerequisites. First of all, basic information about contracting parties must be provided. In the case of clients, it is the name, permanent residence, birth number. For companies and organizations, it is necessary to state the name of the organization, registered office, identification number. The contract also includes the subject of the contract, which is most often the service. The contract also contains information on the scope of services provided, the time interface and the price for the services provided. The prices of services are set in the contracts by agreement between the parties involved. However, the agreed prices according to the contracting approach may not reflect the amount of costs for the contracted services. Thus, contracts can often be disadvantageous for one party. Contracting may therefore lead 
to inefficient allocation of resources. At the same time, there may be a discrepancy between the actual situation and one of the basic goals of the NPM - to support responsible and better provision of services (Act No. 108/2006 Coll.).

In the case of an agreement on cooperation in the provision of social and health services, the inquirer tries to buy the services as cheaply as possible and chooses the most affordable providers from among the available offers. However, this can lead to a price struggle for providers of demanded services. Thus, contracts are often concluded at prices that do not reflect the real costs of the provider but are below their threshold. The price struggle between providers can also lead to a reduction in the quality of the services they provide. Therefore, the quality of social and health services must be regularly checked by the inspection of the provision of social services.

Regarding the contracts concluded between the state and the provider, the origin of the unfavorable contracting of social care is different. The Czech Republic is currently in a situation where social and health services are significantly underfunded. As in other countries, the Czech Republic is gradually aging. The issue of population aging brings with it a larger number of people with requirements for social and health care. According to the analysis of financial costs of social services of the Ministry of Labor and Social Affairs, the costs of homes for the elderly and homes with a special regime increased by 37\% from 2013 to 2018. Although state social welfare contributions are also growing, they are not able to fully cover the requirements of providers. There is a situation where it is necessary to distribute insufficiently large amounts among a large number of facilities (Červenková, 2013; MLSA, 2019).

\section{Conclusions}

Contracting health and social services for patients with AD is a widely used strategy in Czech Republic. Contractors can be either regions, health insurance funds and families as well. Due to the fact that social and health services are highly dependent on public finances of the state, the limited budget for these services may be a significant problem. The lack of funds is manifested mainly in social services, which are partially covered by subsidies. Underfunded social services are a reason for contracting for amounts that are below the real costs of providers. Providers often seek additional financing among clients and their families.

However, public contracting of private providers, which is disadvantageous for social health service providers, can lead to a chain reaction that shifts the need for funding to cover the real costs of care from a public-provider contract to a provider-client relationship. Providers of these services are forced to demand higher direct payments from clients of social and health care facilities, which help them cover the costs of operating the facility.

Although most clients are provided with a care allowance, which helps to cover the costs of the necessary social and health care, this allowance does not always help to cover the amount required for the services provided. The care allowance reaches various values in the Czech Republic, in connection with the health condition and degree of dependence of the patient on the other person. The care allowance is paid in the range from CZK 3,300 to CZK 19,200 . However, the analysis of the financing of social services of the Ministry of Finance 
and Social Affairs shows that even after the inclusion of the care allowance, $21 \%$ of the total costs of social services are covered from clients' own resources. The maximum amounts for social services are limited by Decree No. 505/2006 Coll. Nevertheless, there is often a situation where the prices of social and health care are so high that the family members of the patient are forced to pay for the amount of care provided (MLSA, 2019a, 2020b).

Acknowledgments: This work was supported by the Technology Agency of the Czech Republic (TAČR) under the grant TL01000300.

\section{References}

Act no. 108/2006 On social services. Czech Republic. The Parliament of The Czech Republic. https://www.mpsv.cz/documents/20142/372809/Annex_3_social_services_act.pdf/6ca5e9bd-2308-5c5f-b383bce1d9e09e47

Act no. 48/1997 on Public Health. Czech Republic. The Parliament of The Czech Republic. http://aplikace.mvcr.cz/sbirka-zakonu/ViewFile.aspx?type=c\&id=3007

Červenková, V. (2013). Financování služeb sociální péče pro seniory v ČR - současné problémy a výzvy. Univerzita Karlova v Praze.

Dan, S., \& Pollitt, C. (2015). NPM Can Work: An optimistic review of the impact of New Public Management reforms in central and eastern Europe. Public Management Review, 17(9), 1305-1332. https://doi.org/10.1080/14719037.2014.908662

Drechsler, W., \& Randma-Liiv, T. (2015). The new public management then and now: Lessons from the transition in Central and Eastern Europe. In Implementation of New Public Management Tools. Experiences from transition and emerging countries (pp. 33-49).

Gruening, G. (2001). Origin and theoretical basis of New Public Management. International public management journal, 4(1), 1-25.

Hood, C., \& Dixon, R. (2015). What we have to show for 30 years of new public management: Higher costs, more complaints. Governance, 28(3), 265-267. https://doi.org/10.1111/gove.12150

Kandilaki, D. (2014). Finanční ochrana ve zdravotnictví České republiky v kontextu New Public Managementu (Doctoral dissertation), Vysoká škola ekonomická v Praze.

Kučerová, P. (2014). Financování sociálních služeb v praxi. Univerzita Padrubice.

MPSV - Ministerstvo práce a sociálních věcí (2019). Analýza financování sociálních služeb.

PMSV - Ministerstvo práce a sociálních věcí (2020). Př́spěvek na péči. https://www.mpsv.cz/-/prispevek-na-peci

Pažitný P., \& Kandilaki, D. (2020). Metodologické rámce kalkulace současné ekonomické zátěže. Kontraktingový princip. Projekt TAČR.

Pollitt, C., Van Thiel, S., \& Homburg, V. (2007). New public management in Europe. Basingstoke: Palgrave Macmillan. 